\title{
Effectiveness, Tolerability, and Safety of Tofacitinib in Rheumatoid Arthritis: A Retrospective Analysis of Real-World Data from the St. Gallen and Aarau Cohorts
}

\author{
Ruediger B. Mueller ${ }^{1,2,3, *(\mathbb{D})}$, Caroline Hasler ${ }^{2}$, Florian Popp ${ }^{1}$, Frederik Mattow ${ }^{1}$, \\ Mirsada Durmisi ${ }^{2}$, Alexander Souza ${ }^{4}$, Paul Hasler ${ }^{2}$, Andrea Rubbert-Roth ${ }^{1}$, \\ Hendrik Schulze-Koops ${ }^{3}$ and Johannes von Kempis ${ }^{1}$ \\ 1 Division of Rheumatology and Immunology, Department of Internal Medicine, Kantonsspital St. Gallen, \\ 9007 St. Gallen, Switzerland; fmpopp@gmail.com (F.P.); fmattow@googlemail.com (F.M.); \\ andrea.rubbert-roth@uk-koeln.de (A.R.-R.); johannes.vonkempis@kssg.ch (J.v.K.) \\ 2 Division of Rheumatology, Medical University Department, Kantonsspital Aarau, 5001 Aarau, Switzerland; \\ carolinehasler4@gmail.com (C.H.); m.durmisi@stud.unibas.ch (M.D.); paul.hasler@ksa.ch (P.H.) \\ 3 Division of Rheumatology and Clinical Immunology, Department of Internal Medicine IV, \\ Ludwig-Maximilians-University Munich, 80336 Munich, Germany; \\ Hendrik.Schulze-Koops@med.uni-muenchen.de \\ 4 Iterata AG, 5722 Gränichen, Switzerland; souza@iterata.ch \\ * Correspondence: Ruediger.Mueller@ksa.ch; Tel.: +41-62-838-4688
}

Received: 21 August 2019; Accepted: 24 September 2019; Published: 26 September 2019

Abstract: Introduction: Tofacitinib is an oral JAK inhibitor indicated for the treatment of rheumatoid arthritis (RA). The efficacy and safety of tofacitinib have been shown in several randomized clinical trials. The study presented here aimed to assess the clinical tolerability and effectiveness of tofacitinib among RA patients in real life. Methods: Consecutive patients between January 2015 and April 2017 with RA who fulfilled the American College of Rheumatology (ACR)/European League Against Rheumatism (EULAR) 2010 criteria were included in a prospectively designed analysis of retrospective data. Patients were initiated on tofacitinib $5 \mathrm{mg}$ bid. The primary objective was to analyze the safety of tofacitinib in a real-life cohort. Safety was assessed by the reasons to stop tofacitinib during follow up and changes of liver enzymes, hemoglobin, and creatinine. The secondary outcome was to analyze the frequency of and time to achieve low disease activity (LDA) and remission as defined by 28 joint count disease activity score (DAS28). Results: A total of 144 patients were treated with tofacitinib. A total of $84.9 \%$ of patients were pre-exposed to at least one biological agent. The average DAS28 at the initiation of tofacitinib was 4.43 . A total of $50.0 \%$ of patients were positive for rheumatoid factor and $49.0 \%$ for ACPA. The mean follow up was 1.22 years (range 10d-3.7a) after initiation of tofacitinib treatment. A total of $94(64.4 \%)$ patients remained on tofacitinib during follow-up. The average time to stop tofacitinib was 190.0 days. Reasons to stop tofacitinib were: insufficient response $(n=23)$, gastrointestinal symptoms $(n=18)$, infection $(n=5)$, myalgia $(n=2)$, remission $(n=2)$, headache $(n=2)$, cough, blue finger syndrome, intolerance, heartburn, psoriasis, and increased liver enzymes (all $n=1$ ). Increased alanine amino transferase (ALAT) or aspartate amino transferase (ASAT) $>2 \times$ upper limit of normal (ULN) were detected in $3.3 \%$ and $4.4 \%$ of patients, respectively. Hemoglobin decrease of $>10 \%$ was detected in $15.1 \%$ of the patients and decreased lymphocytes $<500 / \mu \mathrm{L}$ in $3.4 \%$. An increase of creatinine $>20 \%$ was detected in $9.4 \%$ of patients. A total of $62.9 \%$ and $50.0 \%$ of the patients achieved low disease activity (LDA) or remission after a median of 319 and 645 days, respectively. These rates were significantly higher in patients naïve to biologic agents as compared to patients pre-exposed to biologics (LDA: naïve 100\% $92 \mathrm{~d}$, pre-exposed $57.0 \% 434 \mathrm{~d}, p \leq 0.001$; remission: naïve $86.7 \% 132 \mathrm{~d}$, pre-exposed $44.1 \%, 692 \mathrm{~d}, p=0.001$ ). Conclusions: Tofacitinib is a safe and effective treatment option for patients with RA. Tofacitinib may induce high rates of LDA and 
remission in patients with active disease, even after the use of one or more biologics, though the rate appeared higher in patients naïve to biologics. Tofacitinib may be a valuable option in a treat-to-target approach. Our data demonstrate that Janus kinase (JAK) inhibitors are safe and efficacious in real life patients.

Keywords: tofacitinib; rheumatoid arthritis; oral

\section{Introduction}

Rheumatoid arthritis (RA) is a chronic autoimmune disease characterized by the inflammation and destruction of joints. It may result in functional impairment, declining health status and reduced quality of life for affected patients [1-3]. The principal goal in the treatment of RA is to achieve and maintain remission, or, if that is not attainable, low disease activity (LDA) [4,5].

Conventional synthetic (cs) disease-modifying anti-rheumatic drugs (DMARDs), especially methotrexate (MTX), have long been the cornerstones of RA treatment. In the last 20 years, biologic agents have broadened the clinical armamentarium [6]. Though biologics have revolutionized the managing of RA [7-24], their effects are limited. Approximately $50 \%$ of RA patients treated with biologics meet the criteria for low disease activity (28 joint count disease activity score (DAS28) $\leq 3.2$ ) or remission (DAS28 <2.6), while a significant proportion of patients do not achieve an ACR 20 (American College of Rheumatology) response [14,15]. Furthermore, patients on biologics may experience adverse events (AEs) or loss of effectiveness over time [25], e.g., by developing anti-drug antibodies. To quantify the unmet need for additional therapies, Drosos et al. performed a long-term, real-world observational study of their cases with RA treated according to the European League Against Rheumatism (EULAR) and American College of Rheumatology (ACR) recommendations. Approximately one-fifth of their patients did not respond sufficiently to csDMARDs or bDMARDs (biological disease-modifying anti-rheumatic drugs), substantiating the need for alternative treatments [26].

Tofacitinib is a novel, oral Janus kinase (JAK) inhibitor indicated for the treatment of RA. JAK inhibitors are small-molecule drugs that interfere with the activation of JAKs, a family of enzymes implicated in the signaling of leukocytes. JAK signaling has been shown to play an essential role in immune cell generation, differentiation and responses [27-29]. By inhibiting these signaling mechanisms, JAK inhibitors such as tofacitinib have the potential to successfully interfere with immune activation that is critical for RA [30-32] (Koehler, J. Clin. Med. 2019, 8, 938).

Phase II and III clinical trials have shown that the treatment of RA patients with tofacitinib, either as a monotherapy or in combination with csDMARDs, is capable of significantly reducing disease activity, as measured by ACR response rates, EULAR responses and HAQ-DI scores [33-39]. Studies comparing tofacitinib to other therapeutic strategies in the treatment of RA suggest that the effectiveness of tofacitinib is similar to that of biologic agents [40-43]. The safety profile of tofacitinib does not appear to differ significantly from biologics [34,39-44].

In 2012 and 2014, the FDA and the Swissmedic approved tofacitinib for adult patients with moderate to severe RA who had a prior inadequate response to MTX. Approval from the European Medicines Agency (EMA) was granted in 2017. With JAK inhibitors still representing a relatively novel treatment option in the management of RA, there is a demand to use the experience gained through using tofacitinib in a real-life, clinical setting, to further evaluate its safety and utility. In this study, we aimed to analyze real-life data from routine clinical practice to compare our experience with the results of controlled studies. 


\section{Methods}

\subsection{Patient Recruitment}

For this retrospective analysis of data, patients were recruited through a chart review of all RA patients at the hospitals of St. Gallen and Aarau, Switzerland. Patients with a clinical diagnosis of RA consistent with the current definition in the 2010 ACR/EULAR criteria were required [45] and initiation of oral tofacitinib $5 \mathrm{mg}$ bid followed. Exclusion criteria were ages younger than 18 years or older than 80 years at disease onset. All patient charts of the cohort from Aarau and St. Gallen were screened sequentially for eligibility. Thus, selected patients were followed until tofacitinib administration was terminated or until the last visit entered in the database. The decision to stop tofacitinib and all other decisions concerning treatment were at the discretion of the treating clinician. Ethical approval for the collection of patient data was given by the regional review board.

\subsection{Study Design}

This was a longitudinal, retrospective chart review conducted between April 2013 and September 2017 within the St. Gallen and Aarau RA cohorts. The pre-defined primary endpoints were the incidence of adverse events, changes in laboratory values (increase in alanine amino transferase (ALAT) or aspartate amino transferase $($ ASAT) $>1.2$ or 2.0 above the upper limits of normal), decrease in hemoglobin of $>10 \%$, lymphocytes $<500$ or $<1000 / \mu \mathrm{L}$, increase in creatinine $>20 \%$, and adverse events leading to the termination of tofacitinib treatment. The pre-defined secondary clinical endpoint was longitudinal disease activity as measured by DAS28 and the achievement of LDA (DAS28 $\leq 3.2$ ) and remission (DAS28 < 2.6). Data were analyzed for the entire cohort of 144 patients, and, as a secondary analysis, separately for patients who had prior exposure to biologic agents and patients who were naïve to biologic agents.

\subsection{Statistical Methods}

Summary statistics are reported as median (range) or $n(\%)$. Kaplan-Meier curves were plotted, and Kaplan-Meier estimates with 95\% confidence intervals based on a log-log transformation were computed for the endpoints. Time to LDA and remission was compared between patients with and without prior exposure to biologics with a log-rank test. All analyses were performed in the $\mathrm{R}$ programming language (R Foundation, Vienna, Austria, version 3.3.3, R Core Team 2013).

\section{Results}

\subsection{Baseline Demographics}

A total of 144 patients from the rheumatology units of the St. Gallen and Aarau rheumatology divisions fulfilled the inclusion criteria and were included in the cohort. The mean age at initiation of tofacitinib was 59.7 years and mean disease duration was 9.1 years. The majority of patients were female $(69.4 \%)$. A total of $50 \%$ were positive for rheumatoid factor (RF), and $48.6 \%$ were positive for anti-citrullinated protein antibodies (ACPAs), as described in the records. No additional testing for RF and/or ACPA prior or under tofacitinib treatment was conducted. A total of $56 \%$ of the patients were either RF and/or ACPA positive.

Disease activity among the patient cohort was moderate, with a mean DAS28 of 4.43 at the initiation of tofacitinib. A total of $63.3 \%$ had a disease classified as erosive. All patients were initiated on a baseline dose of tofacitinib $5 \mathrm{mg}$ bid. Regarding other medications, the mean number of previous csDMARDS was 1.9. A total of $84.7 \%$ of patients had been previously exposed to at least one biologic agent; the mean number of previous biologics was 2.2. Mean follow-up was 1.22 years (range 10 days-3.7 years) after initiation of tofacitinib (Table 1 ). 
Table 1. Patient demographics.

\begin{tabular}{|c|c|c|c|c|c|}
\hline & All & Stopped & Remained on & Naïve to & After \\
\hline & Patients & \multicolumn{2}{|c|}{ Tofacitinib } & \multicolumn{2}{|c|}{ A Biologic Agent } \\
\hline Number $(n)$ & 144 & 57 & 87 & 22 & 122 \\
\hline Gender $(\%$, female $)$ & 69.4 & 64.9 & 72.4 & 72.7 & 68.8 \\
\hline $\begin{array}{l}\text { Age at initiation tofacitinib (years, } \\
\text { mean) }\end{array}$ & 59.7 & 59.6 & 59.8 & 58.8 & 59.8 \\
\hline $\begin{array}{l}\text { Tofacitinib applied in } \\
\text { monotherapy }(n, \%)\end{array}$ & 65 & 22 & 43 & 14 & 51 \\
\hline \multicolumn{6}{|l|}{ Concomitant medication } \\
\hline - Methotrexate & $36(25.0)$ & $16(28.1)$ & $20(23.0)$ & $5(22.7)$ & $31(25.4)$ \\
\hline - Sulfasalazine & $7(4.9)$ & $4(7.0)$ & $3(3.4)$ & $0(0)$ & $7(5.7)$ \\
\hline - Leflunomide & $25(17.3)$ & $6(10.5)$ & $19(21.8)$ & $3(13.6)$ & $22(18.0)$ \\
\hline - Hydroxychloroquine & $11(7.6)$ & $5(8.8)$ & $6(6.9)$ & $0(0)$ & $11(9.0)$ \\
\hline - Prednisolone or equivalent & $48(33.3)$ & $16(28.1)$ & $32(36.8)$ & $4(18.2)$ & $44(36.1)$ \\
\hline Disease duration (years, mean) & 9.1 & 9.9 & 8.7 & 2.6 & 10.3 \\
\hline \multicolumn{6}{|l|}{$\begin{array}{l}\text { Comorbidities of special interest } \\
\text { Cardiovascular }\end{array}$} \\
\hline - Coronary heart disease & 10 & 2 & 8 & 1 & 9 \\
\hline - Arterial hypertension & 29 & 13 & 16 & 3 & 26 \\
\hline - Dysipoproteinemia & 5 & 2 & 3 & 1 & 4 \\
\hline - Valvular heart disease & 2 & 1 & 1 & 1 & 1 \\
\hline - Adipositas & 12 & 6 & 6 & 0 & 2 \\
\hline - PAD & 3 & 1 & 2 & 0 & 3 \\
\hline Osteoporosis & 39 & 15 & 24 & 4 & 25 \\
\hline After a biologic agent $(\%)$ & 84.7 & 87.2 & 83.5 & 0 & 100 \\
\hline Previous biologic agents ( $n$, mean) & 2.2 & 2.3 & 2.2 & 0 & 2.6 \\
\hline Previous csDMARDs ( $n$, mean) & 1.9 & 1.9 & 1.8 & 1.4 & 1.9 \\
\hline ACPA pos. $(\%)$ & 48.6 & 42.8 & 52.3 & 50.0 & 48.3 \\
\hline Rheumatoid factor pos. (\%) & 50.0 & 51.1 & 48.2 & 40.9 & 51.7 \\
\hline Erosive disease $(\%)$ & 63.3 & 60.9 & 66.7 & 45.5 & 66.7 \\
\hline DAS28 (mean) & 4.4 & 4.4 & 4.5 & 3.7 & 4.6 \\
\hline ESR (mean) & 17.2 & 18.5 & 16.6 & 18.8 & 16.9 \\
\hline CRP (mean, ULN < 5mg/L) & 8.5 & 8.0 & 8.8 & 8.9 & 8.4 \\
\hline
\end{tabular}

$n$ : number. DAS28: 28 joint count disease activity score. DMARDs: disease modifying drugs. ACPA: anti-citrullinated peptide antibody. ESR: erythrocyte sedimentation rate. CRP: C-reactive protein. pos.: positive. ULN: upper limit of normal. PAD: peripheral artery disease.

\subsection{Disease Activity}

For all patients, the mean DAS28 decreased significantly from 4.4 at baseline to $3.59,3.22,3.18$, and 3.13 at $90,180,270$, and 360 days (Figure 1). In total, 53\% of patients achieved LDA and $48 \%$ DAS28 defined remission. The median time to LDA and remission was 319 days and 645 days, respectively.

The rates of LDA and remission under tofacitinib were higher in patients naïve to biologics compared to patients who had been previously exposed: $100 \%$ of naïve patients achieved LDA, and $83.3 \%$ achieved remission, as compared to $53.3 \%$ and $44.9 \%$ of pre-exposed to biologics patients. Also, the duration of tofacitinib treatment until LDA or remission was shorter in patients naïve to biologics. Patients in this cohort achieved LDA after a median 92 days and remission after a median 132 days, while medians for achieving LDA and remission among patients pre-exposed to biologic agents amounted to 434 days and 692 days, respectively. In both cases, the difference between naïve and pre-exposed patients was statistically significant (Figure $2, p<0.001$ ). 


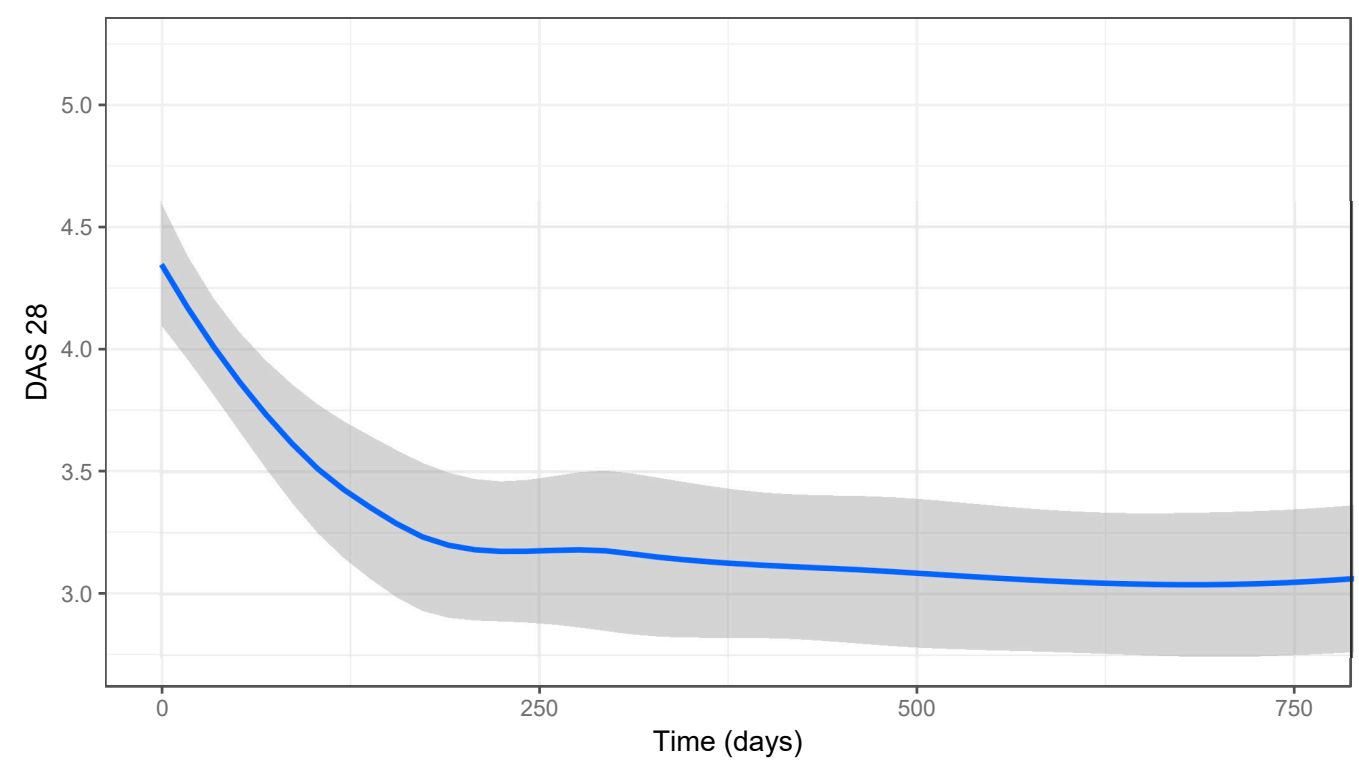

Figure 1. Disease activity: The average disease activity score (DAS28) level is shown for all rheumatoid arthritis (RA) patients treated with tofacitinib with a 95\% confidence interval.
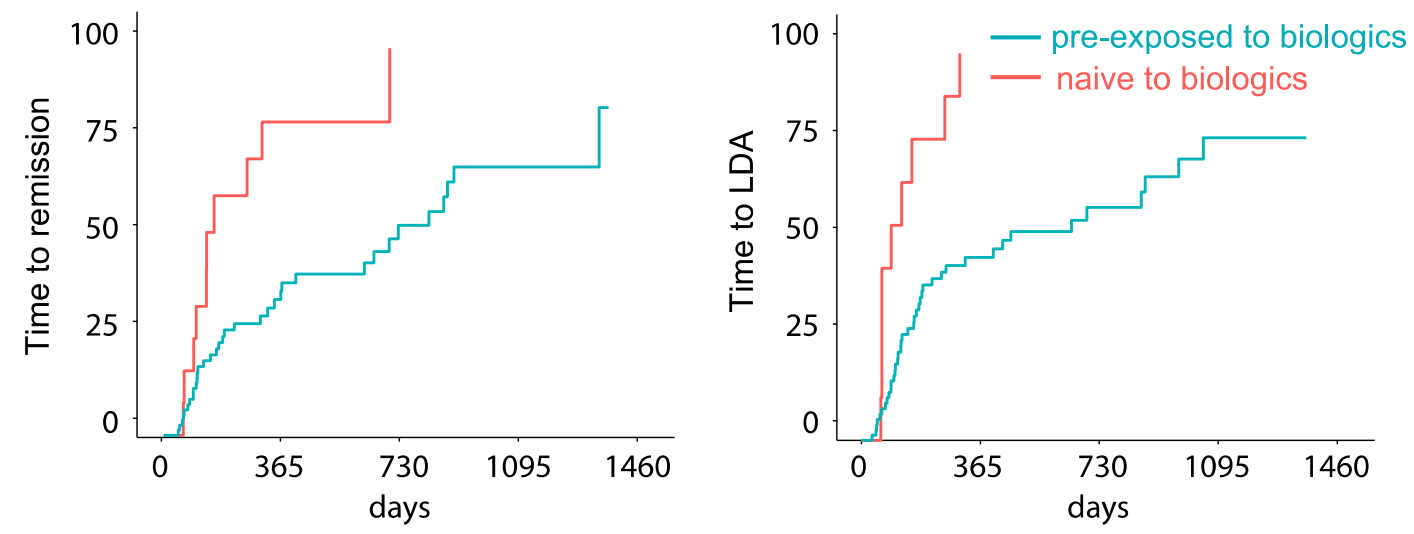

Figure 2. Disease activity: Time to remission (left panel) and low disease activity (LDA, right panel) is shown for all RA patients treated with tofacitinib. Patients previously exposed to biologic agents are shown in green, and patients naïve to biologics in red.

\subsection{Discontinuation}

A total of $89(61.8 \%)$ patients remained on tofacitinib during follow-up. The median time to stop tofacitinib was 95 days (range: 4-1106). A total of 21 patients (14.6\%) stopped tofacitinib due to insufficient responses and 35 patients (23.6\%) stopped due to adverse events (AEs, Table 2). Of these, the most frequent reasons for discontinuing tofacitinib were gastrointestinal symptoms $(n=18)$, followed by infection $(n=5)$, myalgia $(n=2)$, remission $(n=2)$, headache, cough, blue finger syndrome, intolerance, heartburn, psoriasis, and increased liver enzymes (all $n=1$ ). The median time to stop tofacitinib treatment due to ineffectiveness was 204 days (Figure 3). The median time to stop treatment due to AEs ranged from 10 to 290 days (Figure 3). None of the demographic parameters at baseline was a significant predictor for stopping tofacitinib. 
Table 2. Reasons for stopping tofacitinib.

\begin{tabular}{ccc}
\hline Reason & Number & Time to Stop Tofa \\
\hline Inefficacy/flare & $n=22$ & median d204, range d21-d1106 \\
Gastrointestinal & $n=18$ & median d28, range d4-d265d \\
Infection & $n=5$ & median d154, range d85-d877 \\
Myalgia & $n=2$ & range d92-d171 \\
Remission & $n=2$ & range d106-d379 \\
Headache & $n=2$ & $\mathrm{~d} 30$ \\
Cough & $n=1$ & $\mathrm{~d} 22$ \\
Blue finger syndrome & $n=1$ & $\mathrm{~d} 10$ \\
Intolerance & $n=1$ & $\mathrm{~d} 42$ \\
Heartburn & $n=1$ & $\mathrm{~d} 39$ \\
Psoriasis & $n=1$ & $\mathrm{~d} 287$ \\
Increased liver enzymes & $n=1$ & $\mathrm{~d} 290$ \\
\hline
\end{tabular}

d: day. $n$ : number.

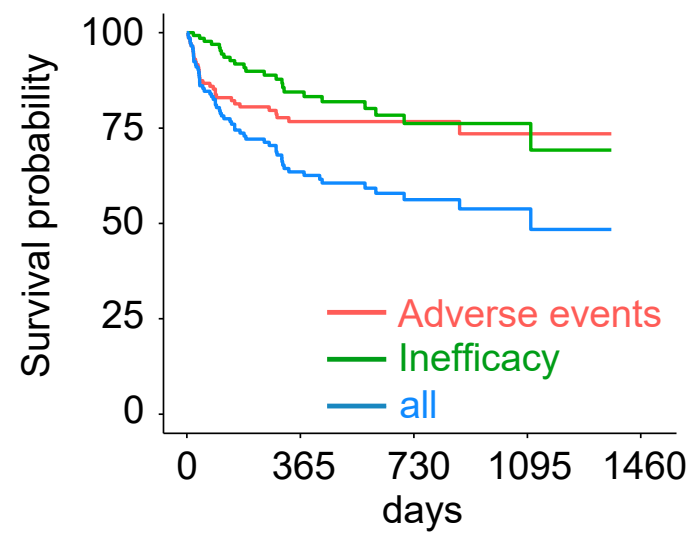

Figure 3. Time to discontinuation of tofacitinib was analyzed for all patients ( $n=57$ out of 144 total patients, blue line). Patients stopping for ineffectiveness $(n=22$, green line) or adverse events $(n=35$, red line) are shown separately.

\subsection{Laboratory Values}

Laboratory values including liver enzymes, creatinine, lymphocyte count, and hemoglobin were followed during tofacitinib treatment. Increased ALAT or ASAT $>2 \times$ ULN were detected in $3.3 \%$ and $4.4 \%$ of patients, respectively. These changes were transient in $50 \%$ and $60 \%$ of cases, respectively. Hemoglobin decrease of $>10 \%$ was detected in $15.1 \%$ of patients and decreased lymphocytes $<500 / \mu \mathrm{L}$ in $3.4 \%$. An increase in creatinine $>20 \%$ was detected in $9.4 \%$ (Figure 4 ).

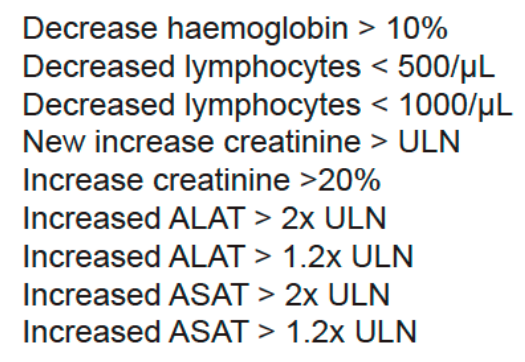

Decrease haemoglobin $>10 \%$ Decreased lymphocytes $<1000 / \mu \mathrm{L}$ New increase creatinine $>$ ULN Increase creatinine $>20 \%$ Increased ALAT > 2x ULN Increased Increased ASAT > 1.2x ULN

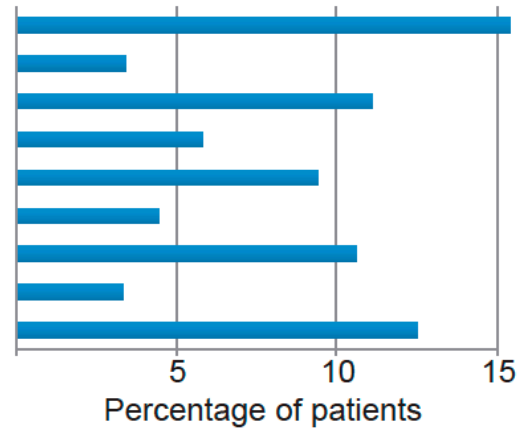

Figure 4. Patients were followed for laboratory changes under treatment with tofacitinib. Data are shown for patients with at least one in- or decrease in one of these parameters during follow-up. Percentages were calculated on patients with available data. ALAT: alanine amino transferase. ASAT: aspartate amino transferase. 


\section{Discussion}

This study retrospectively analyzed real-life data from a cohort of 144 RA patients treated with tofacitinib $5 \mathrm{mg}$ bid, with the aim of assessing the effectiveness and tolerability of tofacitinib in a clinical setting.

\subsection{Effectiveness}

Among the patient cohort, tofacitinib significantly reduced disease activity, with $58.2 \%$ of patients achieving LDA and $49.5 \%$ achieving remission at follow-up. This is a little higher than in published phase I-III clinical trials. In these clinical trials, the overall proportion of RA patients achieving DAS28 defined as was LDA 5.7\%-47.5\% [34,37,43,46,47] and remission $7.2 \%-23.1 \%[34,36,37,43,46-49]$, depending on the exposure to and efficacy of previous treatments. Essentially, our findings corroborate those of previous studies that have shown tofacitinib to be effective in the management of RA [33-37,48,50].

A total of $15.9 \%$ of our patients stopped tofacitinib due to ineffectiveness. Percentages of inefficacy were not published in the pivotal clinical trials, especially as this is not a defined outcome. Therefore, the best approximation may be missing an ACR 20 response. The ACR 20 response was not reached in $33.9 \%$ of the MTX-IR (methotrexate incomplete responders) patients and $48.2 \%$ of the TNF-IR (tumor necrosis factor incomplete responders) patients [51] in the phase II and III program for tofacitinib and $28.7 \%$ of naïve patients [47]. In a long-term extension study, $20.4 \%$ of patients did not achieve ACR 20 after 24 months and 21.5 after 96 months [52]. Importantly, not achieving ACR 20 does not necessarily mean that a patient or a treating physician considers the therapeutic response to, e.g., tofacitinib, ineffective in a clinical setting. Thus, the rate of $15.9 \%$ of patients stopping tofacitinib for ineffectiveness appears to be somewhat lower than observed in the clinical studies and long-term extension studies. However, because, as outlined above, missing an ACR 20 response does not necessarily reflect inefficacy, we think that these rates are comparable.

Although tofacitinib demonstrated effectiveness across all patient demographics, a significant difference was observed between patients naïve to biologic agents and patients who had previously been exposed to biologics: naïve patients had a trend of a higher rate of achieving LDA and remission compared to pre-exposed patients. Also, the duration of tofacitinib treatment until LDA and remission was significantly shorter in patients naïve to biologics. However, the small number of patients naïve to biologics have to be taken into account. These patients naïve to biologics had a shorter mean duration of disease at initiation of tofacitinib and lower mean baseline DAS28, which may have influenced the results. Shorter disease duration [53-55] and lower disease activity at initiation of treatment [56-59] have both been shown to correlate with higher rates of LDA and remission in RA patients. However, the indication that previous biologic therapies are associated with a reduced clinical response to tofacitinib is consistent with recent studies: a meta-analysis of phase II and III clinical trials of tofacitinib in RA patients published in 2016 showed that patients who were naïve to biologics had a numerically better clinical response compared to patients with a prior inadequate response to biologics [60]. This finding was confirmed by a direct comparison study [61] In the 2015, ACR guidelines for the treatment of RA tofacitinib were still recommended as a second-line drug after treatment with biologic agents resulted in an inadequate response or intolerance [62]. In the EULAR guidelines, tofacitinib is already recommended for RA that has inadequately responded to one or more csDMARDs [63].

This is reflected in the patient cohort of the present analysis, in which only $15.2 \%$ of patients were biologic-naïve. However, this and other studies suggest that there is a benefit to be gained from using tofacitinib early in the treatment of RA, before the initiation of biologics, which may call into question the position of tofacitinib as a second-line drug. 


\subsection{Adverse Events}

Few AEs leading to the discontinuation of tofacitinib treatment were observed in this study. Among the AEs that lead to stopping tofacitinib, the most frequent were gastrointestinal AEs, followed by infections. Patients experienced no severe or life-threatening AEs under tofacitinib. The safety profile was comparable to published data, except for a single case of blue finger syndrome [64]. Following initiation, patients developed an increase in LDL cholesterol, which has been established as a side effect of tofacitinib treatment in previous studies $[65,66]$; however, a tofacitinib-induced increase in cholesterol does not appear to be associated with a higher incidence of cardiovascular AEs in patients $[60,65,67]$.

It is interesting that AEs are the main reason for stopping tofacitinib in the period directly following initiation of treatment, later superseded by insufficient therapeutic responses. Treatment had to be stopped for AEs, if necessary, usually rather early in the course of treatment, considering that the average time of follow up was 1.22 years and the mean time to stop tofacitinib was 183 days. Most patients (23\%) discontinued treatment for AEs as early as within the first month (Figure 3). We found no increase in AEs with longer disease duration. Non-tolerability of the drug seems to become apparent rather early after initiation of treatment.

The rate of $24.3 \%$ of patients stopping tofacitinib for adverse events in our study is comparable to the rate of $25 \%$ published in the 9.5 year long-term extension study published by Wollenhaupt et al. [52].

\subsection{Limitations}

A significant limitation of this study is that it deals with real-life data. Follow-ups in real-life practice are not as frequent or consistent as in clinical studies. The size of the patient cohort was also limited, and there was a considerable size difference between the sub-cohorts of patients naïve to biologics and patients with prior exposure. However, the design as a retrospective, whole population real-life analysis also constitutes a strength of this study, as its results reflect the variability of patient populations in medical practice more than data on selected patients in controlled clinical trials.

\section{Conclusions}

The efficacy and safety of tofacitinib have been established in clinical trials. This retrospective analysis of real-life data shows that tofacitinib is also effective and safe in a real-life setting. Over $50 \%$ of the patient cohort achieved LDA or remission on a dose of tofacitinib $5 \mathrm{mg}$ bid, with a higher rate of patients naïve to biologic agents achieving either LDA or remission. The safety profile of tofacitinib was generally consistent with previous studies. In conclusion, our results support the use of tofacitinib in the treatment of RA to achieve a more successful clinical outcome.

Author Contributions: Conceptualization, R.B.M., P.H. and J.v.K.; Data curation, R.B.M. and A.S.; Formal analysis, R.B.M., C.H. and M.D.; Investigation, R.B.M., C.H., F.P., F.M., M.D., A.S., P.H., A.R.-R., H.S.-K. and J.v.K.; Methodology, R.B.M.; Project administration, R.B.M.; Resources, R.B.M.; Software, M.D.; Supervision, R.B.M.; Validation, R.B.M.; Writing—original draft, R.B.M., C.H. and P.H.; Writing-review \& editing, R.B.M.

Conflicts of Interest: The authors declare no conflict of interest. 


\section{Abbreviations}

ACPA anti-citrullinated protein antibody

ACR American College of Rheumatology

AE adverse event

AGREE Abatacept study to gauge remission and joint damage progression in methotrexate-naïve patients with early erosive rheumatoid arthritis

CAMERA Computer Assisted Management in Early Rheumatoid Arthritis

COMET Comparison of methotrexate monotherapy with a combination of methotrexate and

CRP C-reactive protein

Cs Conventional synthetic

DAS Disease Activity Score

DMARD disease-modifying antirheumatic drug

ESR erythrocyte sedimentation rate

EULAR European League Against Rheumatism

GI gastrointestinal

LDA low disease activity

MTX methotrexate

A multicenter, randomized, double-blind clinical trial of combination therapy with

PREMIER adalimumab plus methotrexate versus methotrexate alone or adalimumab alone in patients with early, aggressive rheumatoid arthritis who had not had previous methotrexate treatment

RA rheumatoid arthritis

RF rheumatoid factor

SC subcutaneous

SWEFOT Swedish Farmacotherapy Trial

TEAR Treatment of Early Aggressive Rheumatoid Arthritis

TEMPO Trial of Etanercept and Methotrexate with Radiographic Patient Outcomes

\section{References}

1. Heinimann, K.; Von Kempis, J.; Sauter, R.; Schiff, M.; Sokka-Isler, T.; Schulze-Koops, H.; Müller, R. Long-Term Increase of Radiographic Damage and Disability in Patients with RA in Relation to Disease Duration in the Era of Biologics. Results from the SCQM Cohort. J. Clin. Med. 2018, 7, 57. [CrossRef] [PubMed]

2. Drossaers-Bakker, K.W.; Zwinderman, A.H.; Vlieland, T.P.M.V.; Van Zeben, D.; Vos, K.; Breedveld, F.C.; Hazes, J.M.W.; Drossaers-Bakker, K.W. Long-term outcome in rheumatoid arthritis: A simple algorithm of baseline parameters can predict radiographic damage, disability, and disease course at 12-year followup. Arthritis Rheum. 2002, 47, 383-390. [CrossRef] [PubMed]

3. Eberhardt, K.B.; Fex, E. Functional impairment and disability in early rheumatoid arthritis-development over 5 years. J. Rheumatol. 1995, 22, 1037-1042. [PubMed]

4. Furst, D.E.; Keystone, E.C.; Braun, J.; Breedveld, F.C.; Burmester, G.R.; De Benedetti, F.; Dörner, T.; Emery, P.; Fleischmann, R.; Gibofsky, A.; et al. Updated consensus statement on biological agents for the treatment of rheumatic diseases, 2012. Ann. Rheum. Dis. 2013, 72 (Suppl. 2), ii2-ii34. [CrossRef] [PubMed]

5. Drosos, A.A.; Pelechas, E.; Voulgari, P.V. Rheumatoid Arthritis Treatment. A Back to the Drawing Board Project or High Expectations for Low Unmet Needs? J. Clin. Med. 2019, 8, 1237. [CrossRef] [PubMed]

6. Upchurch, K.S.; Kay, J. Evolution of treatment for rheumatoid arthritis. Rheumatology 2012, 51 (Suppl. 6), vi28-vi36. [CrossRef] [PubMed]

7. Lipsky, P.E.; Van Der Heijde, D.M.; Clair, E.W.S.; Furst, D.E.; Breedveld, F.C.; Kalden, J.R.; Smolen, J.S.; Weisman, M.; Emery, P.; Feldmann, M.; et al. Infliximab and methotrexate in the treatment of rheumatoid arthritis. Anti-Tumor Necrosis Factor Trial in Rheumatoid Arthritis with Concomitant Therapy Study Group. N. Engl. J. Med. 2000, 343, 1594-1602. [CrossRef] 
8. Breedveld, F.C.; Weisman, M.H.; Kavanaugh, A.F.; Cohen, S.B.; Pavelka, K.; van Vollenhoven, R.; Sharp, J.; Perez, J.L.; Spencer-Green, G.T. The PREMIER study: A multicenter, randomized, double-blind clinical trial of combination therapy with adalimumab plus methotrexate versus methotrexate alone or adalimumab alone in patients with early, aggressive rheumatoid arthritis who had not had previous methotrexate treatment. Arthritis Rheum. 2006, 54, 26-37.

9. Moreland, L.W.; Schiff, M.H.; Baumgartner, S.W.; Tindall, E.A.; Fleischmann, R.M.; Bulpitt, K.J.; Weaver, A.L.; Keystone, E.C.; Furst, D.E.; Mease, P.J.; et al. Etanercept therapy in rheumatoid arthritis. A randomized, controlled trial. Ann. Intern. Med. 1999, 130, 478-486. [CrossRef]

10. Clair, E.W.S.; Smolen, J.S.; Maini, R.N.; Bathon, J.M.; Emery, P.; Keystone, E.; Schiff, M.; Kalden, J.R.; Wang, B.; DeWoody, K.; et al. Combination of infliximab and methotrexate therapy for early rheumatoid arthritis: A randomized, controlled trial. Arthritis Rheum. 2004, 50, 3432-3443. [CrossRef]

11. Weinblatt, M.E.; Keystone, E.C.; Furst, D.E.; Moreland, L.W.; Weisman, M.H.; Birbara, C.A.; Teoh, L.A.; Fischkoff, S.A.; Chartash, E.K. Adalimumab, a fully human anti-tumor necrosis factor alpha monoclonal antibody, for the treatment of rheumatoid arthritis in patients taking concomitant methotrexate: The ARMADA trial. Arthritis Rheum. 2003, 48, 35-45. [CrossRef] [PubMed]

12. Maini, R.; Clair, E.W.S.; Breedveld, F.; Furst, D.; Kalden, J.; Weisman, M.; Smolen, J.; Emery, P.; Harriman, G.; Feldmann, M.; et al. Infliximab (chimeric anti-tumour necrosis factor alpha monoclonal antibody) versus placebo in rheumatoid arthritis patients receiving concomitant methotrexate: A randomised phase III trial. Lancet 1999, 354, 1932-1939. [CrossRef]

13. Burmester, G.R.; Mariette, X.; Montecucco, C.; Monteagudo-Saez, I.; Malaise, M.; Tzioufas, A.G.; Bijlsma, J.W.; Unnebrink, K.; Kary, S.; Kupper, H. Adalimumab alone and in combination with disease-modifying antirheumatic drugs for the treatment of rheumatoid arthritis in clinical practice: The Research in Active Rheumatoid Arthritis (ReAct) trial. Ann. Rheum. Dis. 2007, 66, 732-739. [CrossRef] [PubMed]

14. Klareskog, L.; Van Der Heijde, D.; De Jager, J.P.; Gough, A.; Kalden, J.; Malaise, M.; Mola, E.M.; Pavelka, K.; Sany, J.; Settas, L.; et al. Therapeutic effect of the combination of etanercept and methotrexate compared with each treatment alone in patients with rheumatoid arthritis: Double-blind randomised controlled trial. Lancet 2004, 363, 675-681.

15. Keystone, E.C.; Kavanaugh, A.F.; Sharp, J.T.; Tannenbaum, H.; Hua, Y.; Teoh, L.S.; Fischkoff, S.A.; Chartash, E.K. Radiographic, clinical, and functional outcomes of treatment with adalimumab (a human anti-tumor necrosis factor monoclonal antibody) in patients with active rheumatoid arthritis receiving concomitant methotrexate therapy: A randomized, placebo-controlled, 52-week trial. Arthritis Rheum. 2004, 50, 1400-1411. [PubMed]

16. Smolen, J.S.; Kay, J.; Doyle, M.K.; Landewe, R.; Matteson, E.L.; Wollenhaupt, J.; Gaylis, N.; Murphy, F.T.; Neal, J.S.; Zhou, Y.; et al. Golimumab in patients with active rheumatoid arthritis after treatment with tumour necrosis factor alpha inhibitors (GO-AFTER study): A multicentre, randomised, double-blind, placebo-controlled, phase III trial. Lancet 2009, 374, 210-221. [CrossRef]

17. Fleischmann, R.; Vencovsky, J.; van Vollenhoven, R.F.; Borenstein, D.; Box, J.; Coteur, G.; Goel, N.; Brezinschek, H.P.; Innes, A.; Strand, V. Efficacy and safety of certolizumab pegol monotherapy every 4 weeks in patients with rheumatoid arthritis failing previous disease-modifying antirheumatic therapy: The FAST4WARD study. Ann. Rheum. Dis. 2009, 68, 805-811. [CrossRef] [PubMed]

18. Smolen, J.; Landewe, R.B.; Mease, P.; Brzezicki, J.; Mason, D.; Luijtens, K.; van Vollenhoven, R.F.; Kavanaugh, A.; Schiff, M.; Burmester, G.R.; et al. Efficacy and safety of certolizumab pegol plus methotrexate in active rheumatoid arthritis: The RAPID 2 study. A randomised controlled trial. Ann. Rheum. Dis. 2009, 68,797-804. [CrossRef] [PubMed]

19. Emery, P.; Deodhar, A.; Rigby, W.F.; Isaacs, J.D.; Combe, B.; Racewicz, A.J.; Latinis, K.; Abud-Mendoza, C.; Szczepański, L.J.; Roschmann, R.A.; et al. Efficacy and safety of different doses and retreatment of rituximab: A randomised, placebo-controlled trial in patients who are biological naive with active rheumatoid arthritis and an inadequate response to methotrexate (Study Evaluating Rituximab's Efficacy in MTX iNadequate rEsponders (SERENE)). Ann. Rheum. Dis. 2010, 69, 1629-1635. [PubMed]

20. Keystone, E.C.; Genovese, M.C.; Klareskog, L.; Hsia, E.C.; Hall, S.T.; Miranda, P.C.; Pazdur, J.; Bae, S.C.; Palmer, W.; Zrubek, J.; et al. Golimumab, a human antibody to tumour necrosis factor \{alpha\} given by monthly subcutaneous injections, in active rheumatoid arthritis despite methotrexate therapy: The GO-FORWARD Study. Ann. Rheum. Dis. 2009, 68, 789-796. [PubMed] 
21. Schiff, M.; Keiserman, M.; Codding, C.; Songcharoen, S.; Berman, A.; Nayiager, S.; Saldate, C.; Li, T.; Aranda, R.; Becker, J.C.; et al. Efficacy and safety of abatacept or infliximab vs placebo in ATTEST: A phase III, multi-centre, randomised, double-blind, placebo-controlled study in patients with rheumatoid arthritis and an inadequate response to methotrexate. Ann. Rheum. Dis. 2008, 67, 1096-1103. [CrossRef] [PubMed]

22. Jones, G.; Sebba, A.; Gu, J.; Lowenstein, M.B.; Calvo, A.; Gomez-Reino, J.J.; Siri, D.A.; Tomšič, M.; Alecock, E.; Woodworth, T.; et al. Comparison of tocilizumab monotherapy versus methotrexate monotherapy in patients with moderate to severe rheumatoid arthritis: The AMBITION study. Ann. Rheum. Dis. 2010, 69, 88-96. [CrossRef] [PubMed]

23. Bykerk, V.P.; Ostor, A.J.K.; Alvaro-Gracia, J.; Pavelka, K.; Ivorra, J.A.R.; Graninger, W.; Bensen, W.; Nurmohamed, M.T.; Krause, A.; Bernasconi, C.; et al. Comparison of tocilizumab as monotherapy or with add-on disease-modifying antirheumatic drugs in patients with rheumatoid arthritis and inadequate responses to previous treatments: An open-label study close to clinical practice. Clin. Rheumatol. 2015, 34, 563-571. [CrossRef] [PubMed]

24. Nam, J.L.; Ramiro, S.; Gaujoux-Viala, C.; Takase, K.; Leon-Garcia, M.; Emery, P.; Gossec, L.; Landewe, R.; Smolen, J.S.; Buch, M.H. Efficacy of biological disease-modifying antirheumatic drugs: A systematic literature review informing the 2013 update of the EULAR recommendations for the management of rheumatoid arthritis. Ann. Rheum. Dis. 2014, 73, 516-528. [PubMed]

25. Finckh, A.; Simard, J.F.; Duryea, J.; Liang, M.H.; Huang, J.; Daneel, S.; Forster, A.; Gabay, C.; Guerne, P.A. The effectiveness of anti-tumor necrosis factor therapy in preventing progressive radiographic joint damage in rheumatoid arthritis: A population-based study. Arthritis Rheum. 2006, 54, 54-59. [CrossRef] [PubMed]

26. Kaltsonoudis, E.; Pelechas, E.; Voulgari, P.V.; Drosos, A.A. Unmet needs in the treatment of rheumatoid arthritis. An observational study and a real-life experience from a single university center. Semin. Arthritis Rheum. 2019, 48, 597-602. [PubMed]

27. Ghoreschi, K.; Laurence, A.; O'Shea, J.J. Janus kinases in immune cell signaling. Immunol. Rev. 2009, 228, 273-287. [CrossRef]

28. Meyer, D.M.; Jesson, M.I.; Li, X.; Elrick, M.M.; Funckes-Shippy, C.L.; Warner, J.D.; Gross, C.J.; E Dowty, M.; Ramaiah, S.K.; Hirsch, J.L.; et al. Anti-inflammatory activity and neutrophil reductions mediated by the JAK1/JAK3 inhibitor, CP-690,550, in rat adjuvant-induced arthritis. J. Inflamm. 2010, 7, 41.

29. Ortmann, R.A.; Cheng, T.; Visconti, R.; Frucht, D.M.; O'Shea, J.J. Janus kinases and signal transducers and activators of transcription: Their roles in cytokine signaling, development and immunoregulation. Arthritis Res. 2000, 2, 16-32.

30. Ghoreschi, K.; Jesson, M.I.; Li, X.; Lee, J.L.; Ghosh, S.; Alsup, J.W.; Warner, J.D.; Tanaka, M.; Steward-Tharp, S.M.; Gadina, M.; et al. Modulation of innate and adaptive immune responses by tofacitinib (CP-690,550). J. Immunol. 2011, 186, 4234-4243.

31. O'Shea, J.J.; Laurence, A.; McInnes, I.B. Back to the future: Oral targeted therapy for RA and other autoimmune diseases. Nat. Rev. Rheumatol. 2013, 9, 173-182. [CrossRef] [PubMed]

32. Maeshima, K.; Yamaoka, K.; Kubo, S.; Nakano, K.; Iwata, S.; Saito, K.; Ohishi, M.; Miyahara, H.; Tanaka, S.; Ishii, K.; et al. The JAK inhibitor tofacitinib regulates synovitis through inhibition of interferon-gamma and interleukin-17 production by human CD4 ${ }^{+}$T cells. Arthritis Rheum. 2012, 64, 1790-1798. [CrossRef] [PubMed]

33. Coombs, J.H.; Bloom, B.J.; Breedveld, F.C.; Fletcher, M.P.; Gruben, D.; Kremer, J.M.; Burgos-Vargas, R.; Wilkinson, B.; Zerbini, C.A.; Zwillich, S.H. Improved pain, physical functioning and health status in patients with rheumatoid arthritis treated with CP-690,550, an orally active Janus kinase (JAK) inhibitor: Results from a randomised, double-blind, placebo-controlled trial. Ann. Rheum. Dis. 2010, 69, 413-416. [CrossRef] [PubMed]

34. Burmester, G.R.; Blanco, R.; Charles-Schoeman, C.; Wollenhaupt, J.; Zerbini, C.; Benda, B.; Gruben, D.; Wallenstein, G.; Krishnaswami, S.; Zwillich, S.H.; et al. Tofacitinib (CP-690,550) in combination with methotrexate in patients with active rheumatoid arthritis with an inadequate response to tumour necrosis factor inhibitors: A randomised phase 3 trial. Lancet 2013, 381, 451-460. [CrossRef]

35. Fleischmann, R.; Kremer, J.; Cush, J.; Schulze-Koops, H.; Connell, C.A.; Bradley, J.D.; Gruben, D.; Wallenstein, G.V.; Zwillich, S.H.; Kanik, K.S. Placebo-controlled trial of tofacitinib monotherapy in rheumatoid arthritis. N. Engl. J. Med. 2012, 367, 495-507. [CrossRef] [PubMed] 
36. Kremer, J.; Li, Z.-G.; Hall, S.; Fleischmann, R.; Genovese, M.; Martín-Mola, E.; Isaacs, J.D.; Gruben, D.; Wallenstein, G.; Krishnaswami, S.; et al. Tofacitinib in combination with nonbiologic disease-modifying antirheumatic drugs in patients with active rheumatoid arthritis: A randomized trial. Ann. Intern. Med. 2013, 159, 253-261. [CrossRef] [PubMed]

37. Wollenhaupt, J.; Silverfield, J.; Lee, E.B.; Curtis, J.R.; Wood, S.P.; Soma, K.; Nduaka, C.I.; Benda, B.; Gruben, D.; Nakamura, H.; et al. Safety and efficacy of tofacitinib, an oral janus kinase inhibitor, for the treatment of rheumatoid arthritis in open-label, longterm extension studies. J. Rheumatol. 2014, 41, 837-852. [CrossRef] [PubMed]

38. Kremer, J.M.; Cohen, S.; Wilkinson, B.E.; Connell, C.A.; French, J.L.; Gómez-Reino, J.; Gruben, D.; Kanik, K.S.; Krishnaswami, S.; Pascual-Ramos, V.; et al. A phase Ilb dose-ranging study of the oral JAK inhibitor tofacitinib (CP-690,550) versus placebo in combination with background methotrexate in patients with active rheumatoid arthritis and an inadequate response to methotrexate alone. Arthritis Rheum. 2012, 64, $970-981$. [CrossRef]

39. Tanaka, Y.; Suzuki, M.; Nakamura, H.; Toyoizumi, S.; Zwillich, S.H. Tofacitinib Study I. Phase II study of tofacitinib (CP-690,550) combined with methotrexate in patients with rheumatoid arthritis and an inadequate response to methotrexate. Arthritis Care Res. 2011, 63, 1150-1158. [CrossRef]

40. Wagner, S.; Forejtova, S.; Zwillich, S.H.; Gruben, D.; Koncz, T.; Wallenstein, G.V.; Krishnaswami, S.; Bradley, J.D.; Van Vollenhoven, R.F.; Fleischmann, R.; et al. Tofacitinib or adalimumab versus placebo in rheumatoid arthritis. N. Engl. J. Med. 2012, 367, 508-519.

41. Vieira, M.C.; Zwillich, S.H.; Jansen, J.P.; Smiechowski, B.; Spurden, D.; Wallenstein, G.V. Tofacitinib Versus Biologic Treatments in Patients With Active Rheumatoid Arthritis Who Have Had an Inadequate Response to Tumor Necrosis Factor Inhibitors: Results From a Network Meta-analysis. Clin. Ther. 2016, 38, 2628-2641.e5. [CrossRef] [PubMed]

42. Bergrath, E.; Gerber, R.A.; Gruben, D.; Lukic, T.; Makin, C.; Wallenstein, G. Tofacitinib versus Biologic Treatments in Moderate-to-Severe Rheumatoid Arthritis Patients Who Have Had an Inadequate Response to Nonbiologic DMARDs: Systematic Literature Review and Network Meta-Analysis. Int. J. Rheumatol. 2017, 2017, 8417249. [CrossRef] [PubMed]

43. Fleischmann, R.; Mysler, E.; Luo, Z.; Demasi, R.; Soma, K.; Zhang, R.; Takiya, L.; Tatulych, S.; Mojcik, C.; Krishnaswami, S.; et al. Efficacy and safety of tofacitinib monotherapy, tofacitinib with methotrexate, and adalimumab with methotrexate in patients with rheumatoid arthritis (ORAL Strategy): A phase 3b/4, double-blind, head-to-head, randomised controlled trial. Lancet 2017, 390, 457-468. [CrossRef]

44. Fleischmann, R.; Cutolo, M.; Genovese, M.C.; Lee, E.B.; Kanik, K.S.; Sadis, S.; Connell, C.A.; Gruben, D.; Krishnaswami, S.; Wallenstein, G.; et al. Phase IIb dose-ranging study of the oral JAK inhibitor tofacitinib (CP-690,550) or adalimumab monotherapy versus placebo in patients with active rheumatoid arthritis with an inadequate response to disease-modifying antirheumatic drugs. Arthritis Rheum. 2012, 64, 617-629. [CrossRef] [PubMed]

45. Aletaha, D.; Neogi, T.; Silman, A.J.; Funovits, J.; Felson, D.T.; Bingham, C.O.; Birnbaum, N.S.; Burmester, G.R.; Bykerk, V.P.; Cohen, M.D.; et al. 2010 rheumatoid arthritis classification criteria: An American College of Rheumatology/European League Against Rheumatism collaborative initiative. Ann. Rheum. Dis. 2010, 69, 1580-1588. [CrossRef] [PubMed]

46. Iwamoto, N.; Tsuji, S.; Takatani, A.; Shimizu, T.; Fukui, S.; Umeda, M.; Nishino, A.; Horai, Y.; Koga, T.; Kawashiri, S.-Y.; et al. Efficacy and safety at 24 weeks of daily clinical use of tofacitinib in patients with rheumatoid arthritis. PLoS ONE. 2017, 12, e0177057. [CrossRef] [PubMed]

47. Wilkinson, B.; Krishnaswami, S.; Van Vollenhoven, R.F.; Sexton, D.; Yuan, K.; Chen, J.; Xu, A. Tofacitinib versus methotrexate in rheumatoid arthritis. N. Engl. J. Med. 2014, 370, 2377-2386.

48. Van Der Heijde, D.; Tanaka, Y.; Fleischmann, R.; Keystone, E.; Kremer, J.; Zerbini, C.; Cardiel, M.H.; Cohen, S.; Nash, P.; Song, Y.-W.; et al. Tofacitinib (CP-690,550) in patients with rheumatoid arthritis receiving methotrexate: Twelve-month data from a twenty-four-month phase III randomized radiographic study. Arthritis Rheum. 2013, 65, 559-570. [CrossRef]

49. Smolen, J.S.; Aletaha, D.; Gruben, D.; Zwillich, S.H.; Krishnaswami, S.; Mebus, C. Brief Report: Remission Rates With Tofacitinib Treatment in Rheumatoid Arthritis: A Comparison of Various Remission Criteria. Arthritis Rheumatol. 2017, 69, 728-734. [CrossRef] 
50. Kremer, J.M.; Bloom, B.J.; Breedveld, F.C.; Coombs, J.H.; Fletcher, M.P.; Gruben, D.; Krishnaswami, S.; Burgos-Vargas, R.; Wilkinson, B.; Zerbini, C.A.F.; et al. The safety and efficacy of a JAK inhibitor in patients with active rheumatoid arthritis: Results of a double-blind, placebo-controlled phase IIa trial of three dosage levels of CP-690,550 versus placebo. Arthritis Rheum. 2009, 60, 1895-1905. [CrossRef]

51. Charles-Schoeman, C.; Burmester, G.; Nash, P.; Zerbini, C.A.; Soma, K.; Kwok, K.; Hendrikx, T.; Bananis, E.; Fleischmann, R. Efficacy and safety of tofacitinib following inadequate response to conventional synthetic or biological disease-modifying antirheumatic drugs. Ann. Rheum. Dis. 2016, 75, 1293-1301. [CrossRef] [PubMed]

52. Wollenhaupt, J.; Lee, E.-B.; Curtis, J.R.; Silverfield, J.; Terry, K.; Soma, K.; Mojcik, C.; Demasi, R.; Strengholt, S.; Kwok, K.; et al. Safety and efficacy of tofacitinib for up to 9.5 years in the treatment of rheumatoid arthritis: Final results of a global, open-label, long-term extension study. Arthritis Res. Ther. 2019, 21, 89. [CrossRef] [PubMed]

53. Anderson, D.R.; Patil, S.; Kamina, A.; Penson, D.F.; Peduzzi, P.; Concato, J. Validation of a staging system for evaluating prognosis in prostate cancer. Connect. Med. 2000, 64, 459-464.

54. Harrold, L.R.; Litman, H.J.; Connolly, S.E.; Kelly, S.; Hua, W.; Alemao, E.; Rosenblatt, L.; Rebello, S.; Kremer, J.M. A window of opportunity for abatacept in RA: is disease duration an independent predictor of low disease activity/remission in clinical practice? Clin. Rheumatol. 2017, 36, 1215-1220. [CrossRef] [PubMed]

55. Furst, D.E.; Pangan, A.L.; Harrold, L.R.; Chang, H.; Reed, G.; Kremer, J.M.; Greenberg, J.D. Greater likelihood of remission in rheumatoid arthritis patients treated earlier in the disease course: Results from the Consortium of Rheumatology Researchers of North America registry. Arthritis Care Res. 2011, 63, 856-864. [CrossRef]

56. Vastesaeger, N.; Kutzbach, A.G.; Amital, H.; Pavelka, K.; Lazaro, M.A.; Moots, R.J.; Wollenhaupt, J.; Zerbini, C.A.F.; Louw, I.; Combe, B.; et al. Prediction of remission and low disease activity in disease-modifying anti-rheumatic drug-refractory patients with rheumatoid arthritis treated with golimumab. Rheumatology 2016, 55, 1466-1476. [CrossRef]

57. Aletaha, D.; Funovits, J.; Keystone, E.C.; Smolen, J.S. Disease activity early in the course of treatment predicts response to therapy after one year in rheumatoid arthritis patients. Arthritis Rheum. 2007, 56, 3226-3235. [CrossRef]

58. Smolen, J.S.; Szumski, A.; Koenig, A.S.; Jones, T.V.; Marshall, L. Predictors of remission with etanercept-methotrexate induction therapy and loss of remission with etanercept maintenance, reduction, or withdrawal in moderately active rheumatoid arthritis: Results of the PRESERVE trial. Arthritis Res. Ther. 2018, 20, 8. [CrossRef]

59. Kavanaugh, A.; Keystone, E.; Greenberg, J.D.; Reed, G.W.; Griffith, J.M.; Friedman, A.W.; Saunders, K.C.; Ganguli, A. Benefit of biologics initiation in moderate versus severe rheumatoid arthritis: Evidence from a United States registry. Rheumatology 2017, 56, 1095-1101. [CrossRef]

60. Charles-Schoeman, C.; Gonzalez-Gay, M.A.; Kaplan, I.; Boy, M.; Geier, J.; Luo, Z.; Zuckerman, A.; Riese, R. Effects of tofacitinib and other DMARDs on lipid profiles in rheumatoid arthritis: Implications for the rheumatologist. Semin Arthritis Rheum. 2016, 46, 71-80. [CrossRef]

61. Mori, S.; Yoshitama, T.; Ueki, Y. Tofacitinib Therapy for Rheumatoid Arthritis: A Direct Comparison Study between Biologic-naive and Experienced Patients. Intern. Med. 2018, 57, 663-670. [CrossRef] [PubMed]

62. Singh, J.A.; Saag, K.G.; Bridges, S.L.; Akl, E.A.; Bannuru, R.R.; Sullivan, M.C.; Vaysbrot, E.; McNaughton, C.; Osani, M.; Shmerling, R.H.; et al. 2015 American College of Rheumatology Guideline for the Treatment of Rheumatoid Arthritis. Arthritis Rheumatol. 2016, 68, 1-26. [CrossRef] [PubMed]

63. Smolen, J.S.; Breedveld, F.C.; Burmester, G.R.; Bykerk, V.; Dougados, M.; Emery, P.; Kvien, T.K.; Navarro-Compán, M.V.; Oliver, S.; Schoels, M.; et al. Treating rheumatoid arthritis to target: 2014 update of the recommendations of an international task force. Ann. Rheum. Dis. 2016, 75, 3-15. [CrossRef] [PubMed]

64. Popp, F.; Semela, D.; von Kempis, J.; Mueller, R.B. Improvement of primary biliary cholangitis (PBC) under treatment with sulfasalazine and abatacept. BMJ Case Rep. 2018. [CrossRef] [PubMed]

65. Wu, J.J.; Strober, B.E.; Hansen, P.R.; Ahlehoff, O.; Egeberg, A.; Qureshi, A.A.; Robertson, D.; Valdez, H.; Tan, H.; Wolk, R. Effects of tofacitinib on cardiovascular risk factors and cardiovascular outcomes based on phase III and long-term extension data in patients with plaque psoriasis. J. Am. Acad. Dermatol. 2016, 75, 897-905. [CrossRef] 
66. Wolk, R.; Armstrong, E.J.; Hansen, P.R.; Thiers, B.; Lan, S.; Tallman, A.M.; Kaur, M.; Tatulych, S. Effect of tofacitinib on lipid levels and lipid-related parameters in patients with moderate to severe psoriasis. J. Clin. Lipidol. 2017, 11, 1243-1256. [CrossRef] [PubMed]

67. Charles-Schoeman, C.; Wicker, P.; Gonzalez-Gay, M.A.; Boy, M.; Zuckerman, A.; Soma, K.; Geier, J.; Kwok, K.; Riese, R. Cardiovascular safety findings in patients with rheumatoid arthritis treated with tofacitinib, an oral Janus kinase inhibitor. Semin. Arthritis Rheum. 2016, 46, 261-271. [CrossRef] [PubMed]

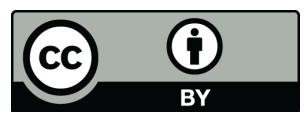

(C) 2019 by the authors. Licensee MDPI, Basel, Switzerland. This article is an open access article distributed under the terms and conditions of the Creative Commons Attribution (CC BY) license (http://creativecommons.org/licenses/by/4.0/). 